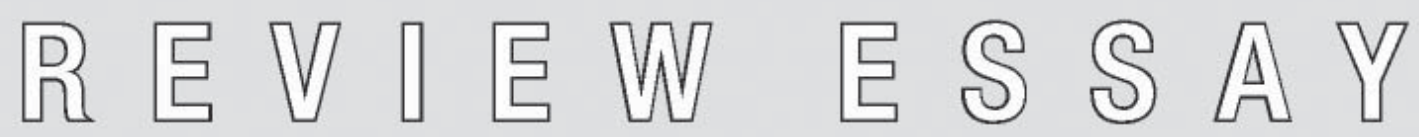

af J akob Skovgaard-Petersen

\title{
Er orientalisterne orientalister?
}

2008 er 30-året for udgivelsen af Edward Saids Orientalism. Og den er stadig aktuel, hvis man skal tro nogle nye bøger, som angriber den. Det er dog et spørgsmål, om man skal det. Not everything is Said in Middle Eastern Studies.

Robert Irwin 2008: Af begær efter viden. Orientalisterne og deres fjender. København: Forlaget Vandkunsten.

Ibn Warraq 2007: Defending the West. A Critique of Edward Said's Orientalism. New York: Prometheus Books.

\section{Til forsvar for orientalisterne}

Afbegær efter viden er allerede oversat til dansk. Den er skrevet af den skønlitterære forfatter og orientalist Robert Irwin, mangeårig anmelder af bøger om Orienten for the Times Literary Supplement. Irwin vil med denne bog to ting: for det første vil han forsvare orientalisterne imod Edward Said, for det andet vil han skrive en mere retvisende orientalistikkens historie. Han har held med begge dele et langt stykke hen ad vejen. Når det ikke gælder hele vejen, så skyldes det, at de to hensigter kommer på tværs af hinanden.

Langt hovedparten af bogen er en faghistorie. Orientalistikken har en lang historie, i alt fald en lang begyndelse, idet man i de tidlige europæiske universiteter med mellemrum beskæftigede sig med Orienten og islam, ofte men ikke altid i polemisk øjemed. Fra oversættelsen af Koranen til latin i 1200-tallet har der også været europæere, der - uden ligefrem at være tiltrukket af religionen 
islam - dog var så fascinerede af deres emne, at de somme tider måtte skjule denne fascination bag behørige fordømmelser. Irwin, der selv har middelalderen som speciale, skriver med stort overblik historien om fagets fremkomst og tidlige udvikling gennem renæssance, rationalisme og romantik. Modsat Said er historien her ikke bare engelsk og fransk, men også russisk, spansk, hollandsk, tysk og tilmed dansk. Den franske og britiske historie under kolonialismen er også fortalt helt anderledes, nemlig som den svage forbindelse til imperialismen. Selv i Imperiets blomstringstid var studierne i Cambridge og Oxford for størstedelen rettet imod den arabiske og persiske "guldalder" i perioden 800-1300, og ikke imod samtidens orientalske samfund. Men 1700 og 1800-tallets orientalistik var, som Irwin beretter, domineret af tyskere og hollændere. Irwin gør en del ud af at skrive en række læsværdige personlige portrætter af store orientalister. Og hvor Said skal "afsløre" deres onde intentioner, finder Irwin i det fleste tilfælde, at drivkraften var et "begær efter viden", ofte i en yderst excentrisk indpakning. Igennem denne historie henviser Irwin flere gange til Orientalism, men altid for at demonstrere, hvor komplet Said har misrepræsenteret bestemte orientalister eller temaer.

Denne fornemme faghistorie udarter imidlertid i den sidste del om perioden efter 1945. For her lader Irwin i lighed med Kramer alt ondt udgå fra Edward Said. Det betyder, at Said og dem han kritiserer, og dem der kritiserer Said, spiller en altdominerende rolle i disse kapitler. Og det er som nævnt forkert. På de felter som jeg kender til, f.eks. studiet af islamisk lov, mystik, ideologier, embeder og institutioner, overser Irwin komplet de meget betragtelige fremskridt, der er sket i forskningen de sidste fyrre år, hvor nye metoder, nye temaer og ikke mindst nye kildetyper helt har revolutioneret feltet. Der var f.eks. ikke megen interessant antropologi fra Mellemøsten i 1960erne, og slet intet om f.eks. mellemøstlige storbyer, men i dag er der bunkevis, og det samme kan siges inden for en række andre studier, f.eks. af kvinder, undervisning, retspraksis eller sociale bevægelser. Irwin kender kort sagt ikke meget til det nutidige studium af Mellemøsten og dets mennesker og vælger derfor i stedet at følge Saids "kanonisering" af enkelte ældre højreorienterede forskere som Lewis, Kedouri eller Vatikiotis. Kapitlet om de nutidige studier slutter med at begræde udviklingen i Storbritannien, hvor Irwin mener, at skiftende regeringers humaniorafjendske forskningspolitik i samklang med Saidismen har svækket orientalistikkens status og selvsikkerhed. Måske. Men overordnet set blomstrer studiet af Mellemøsten i både nutid og fortid, hvilket de righoldige kataloger fra førende forlæggere klart illustrerer.

Irwin opsummerer elegant mange af kritikpunkterne imod Saids Orientalism - både andres og dem han selv lige har påvist i sin historie. Men han føler sig også kaldet til at forsvare de nutidige forskere, som Said særligt har angrebet. Det har han imidlertid vanskeligt ved. For forskere som Bernard Lewis har givet et billede af den muslimske verden som relativt ensartet og helt domineret af en nærved uforanderlig islam, hvis begreber og ord han tillæg- 
ger en direkte effekt i måden, som samfund og stater fungerer på. Det gælder udpræget i hans mere populariserende bøger som What Went Wrong?, der er oversat til dansk. Ligesom Lewis også har været involveret i politisk mobilisering, senest for at USA skulle invadere Irak. Det havde nok været klogere for Irwin at vedgå, at træk af Saids orientalisme findes i orientalistikken, men at den er langt rigere og mere varieret, og at det kan være legitimt som Lewis at diskutere spørgsmålet om kontinuitet og betydningen af teologiske og juridiske dogmer i den muslimske verden og offentlighed, også i dag. Selv om man så - modsat Lewis - bør gøre det ud fra nutidige muslimske kilder og diskutere deres relation til deres samtid og nære førnutid, snarere en simpelthen at postulere deres gæld til en fjernere datid.

\section{Til forsvar for Vesten}

Ibn Warraqs Defending the West angiver også som undertitel, at bogen er en kritik af Saids Orientalism. Her har han ikke lovet for meget; det er en stærkt polemisk bog, der ligesom Irwin samtidigt gerne vil vise, hvordan orientalistikken i virkeligheden har været. Alligevel er de to bøger ret forskellige.

Ibn Warraq er et pseudonym for en pakistansk forfatter, der har studeret i Storbritannien og igennem de seneste tretten år har udgivet en række bøger, der er stærkt kritiske over for islam. Den første, Why I am not a Muslim (også oversat til dansk i 2004), er et general-opgør med islam. Det føres på flere niveauer, og efter min mening ikke synderligt konsistent; første halvdel handler om den tidlige islam i 6-700 tallet, mens anden halvdel beskæftiger sig med de forhold ved islam, Ibn Warraq mener er særligt forkastelige. Samtlige kapitler har til formål at demonstrere forskellige sider af islams talløse urimeligheder, historisk, politisk, moralsk, samt at angribe islam-forskere, der måtte have ment noget andet, for at være apologeter eller relativister. Ibn Warraq roder sig imidlertid ud i temmelig mange selvmodsigelser, fordi han ikke gør noget forsøg på at tage stilling til indbyrdes modstridende tolkninger af den tidlige islam, idet hans kriterium alene har været, at de skal dømme Muhammad og den islamiske tradition hårdt.

Siden denne bog har Ibn Warraq udgivet nogle større antologier med tekster af orientalister om Koranen og Muhammad, forsynet med velskrevne indledninger af ham selv. Motivet har, som i den første bog, været at mobilisere vestlig orientalistik i kampen mod nutidig islam. Men her på en i mine øjne mere acceptabel måde end i den første bog. Dels har Ibn Warraq jo gjort os den tjeneste at optrykke og tilgængeliggøre væsentlige videnskabelige artikler fra obskure fagtidsskrifter, og dels har han ladet dem tale for sig selv. Dog er der nok i praksis sket det, at langt de fleste læsere nøjes med Ibn Warraqs indledning med alle de politiske pointer og derpå springer over de vanskelige og detaljerede artikler, der derfor mest har en rolle som autoritetspåkaldelse. Min eneste indvending vil være, at han i lighed med Why I am not a Muslim indtager - og propagerer - den naive indstilling, at forskere, der udlægger 
den tidlige muslimske historie på en måde der står langt fra den muslimske historiografi, må være modige og videnskabelige. Mens forskere, hvis resultater er tættere på den muslimske tradition, må være apologeter og feje. Det er naturligvis noget nonsens, og ikke lige dét, vi har brug for i arbejdet med at forstå den tidlige islamiske periode. Med lidt omtanke vil enhver kunne sige sig selv, at de muslimske kilder er blandt de bedste vi har, og at det gælder om at anvende dem med nøjagtigt lige så kritisk en attitude, som vi anvender på de ikke-muslimske kilder.

Og nu kommer så bogen om Edward Said og orientalisterne som led i det samme ideologiske opgør med en underligt udefineret "islam". Ligesom Irwin vil Ibn Warraq rense orientalisterne for Saids angreb, men det kommer der en langt mere rodet og svag fremstilling ud af - også i forhold til Ibn Warraqs tidligere bøger. Grunden til det forklarer han for så vidt selv i indledningen, hvoraf det fremgår, at bogen består af tre separate dele: et ti år gammelt essay, der angriber "Edward Said and the Saidists", en lang del to om "The three golden threads and the misapprehensions of Edward Said" og en sidste lang del om "Orientalism in painting and sculpture, music and literature."

Den sidste del skal ikke beskæftige os her. Det er en demonstration af, at vestlige kunstnere i det store og hele har lavet mange positive og inspirerede fremstillinger af Orienten - modsat hvad nogle forskere i kølvandet på Said ellers hævdede i 1980erne. Det har Ibn Warraq helt ret i, men det er blevet effektivt og kyndigt demonstreret af John Mackenzie i bogen Orientalism. History, Theory and the Arts fra 1995. Også i det første essay er det i det store og hele kritikpunkter, man har hørt og læst før - og nu ikke i obskure fagtidsskrifter, men mere generelt. Det er mere ved sin heftighed end ved sin substans, at ibn Warraq skiller sig ud; essayet ender ligefrem med at spørge, hvorfor Said ikke konverterer til islam, den religion han "altid forsvarer" (s. 54).

Som så mange andre kritiserer Ibn Warraq Saids indviklede og prætentiøse sprog og historiske fejltagelser. En vægtigere indvending er Saids manglende viden om de indo-ariske sprog og om Dantes "Guddommelige komedie", som Said netop gør noget ud af. Som også Irwin påpeger, er Muhammad i Dantes helvede simpelthen fordi han ikke er døbt. Ibn Warraq fortsætter mere på egen hånd, når han kritiserer Said for at misforstå vestlig civilisation. Som i sine øvrige bøger laver Ibn Warraq i høj grad en citat-mosaik, hvor mere betydende forskere giver belæg til hans tekst. I dette kapitel særligt fra Maxime Rodinsons bog om orientalistikkens historie, Europe et la fascination de 'l-Islam. Hvad Ibn Warraq dog ikke nævner er, at Rodinson i høj grad så orientalistikken som forbundet med imperialismen, ligesom han heller ikke havde problemer med at karakterisere megen orientalistik som netop den form for ideologi om anderledeshed på tyndt videnskabeligt grundlag, som Said talte om. Rodinson fandt bare ikke Saids bog korrekt i mange sager og var - som også Ibn Warraq og Irwin - stærkt kritisk over for den form for ideologisk anti-imperialisme i den tredje verden (og blandt sympatisører i Vesten), som 
sidestillede god videnskab med god ideologi. For der er ingen forbindelse.

Og det er her, Ibn Warraq for alvor går galt i byen. For også han føler sig åbenbart kaldet til at lave "god ideologisk videnskab" og fælde domme over hele civilisationer og alt, hvad de har bedrevet. De tre gyldne tråde i Vestens historie, som han udnævner i anden del af bogen, er rationalisme, universalisme og selv-kritik. Ibn Warraq påstår, at disse dyder altovervejende er vestlige, og at de navnligt er så godt som fraværende i den islamiske tradition. Denne påstand er så generel, og anvendelsen af civilisationsbegrebet så løst, at de 250 siders gennemgang ikke ender med at overbevise. Faktisk ender de med at give en underlig fornemmelse af beslutsom selektiv ensidighed, der leder tanken hen på - ja, Saids Orientalism, dér hvor den er værst. Jeg har selv ofte nok skullet bruge krudt på at forsvare Vesten i debatter i den Arabiske Verden, men her sidder jeg tilbage med en følelse af, at med venner som disse...

At der er lange traditioner i den vestlige verden for rationalisme, universalisme og selvkritik, er både åbenlyst og noget at være stolt af. Ibn Warraq bekender sig - som så mange af os andre - stærkt til disse værdier. Men her er det fremstillet som et vestligt særkende, en hegeliansk ånd, der åbenbarer sig igennem den vestlige historie. Her synes jeg, man skal være endog meget beslutsom for at overse, at den vestlige historie også udviser stærke traditioner for irrationalisme, partikularisme og ukritisk selvfejring. Ironisk nok læner denne bog sig netop op ad den sidstnævnte holdning. Faktisk har repræsentanter for rationalisme, universalisme og selvkritik aldrig savnet opponenter og fjender i den vestlige historie, som i parentes bemærket også i det tyvende århundrede har udvist fatale eksempler på politisk irrationalisme og etnisk eksklusivisme i en grad, så resten af verden kiggede forfærdet på.

Men det kan læseren selv overveje; det er ikke noget, jeg har særligt forstand på. Det forekommer mig derfor mere nyttigt at knytte nogle kommentarer til Ibn Warraqs opfattelse af, at rationalisme, universalisme og selv-kritik ikke forekommer i en islamisk sammenhæng.

Efter en gennemgang af vestlig rationalisme fra Aristoteles til John Henry Newman siger Ibn Warraq (s. 52 ff.), at det ikke er noget man finder i den islamiske verden, hvor man aldrig har udvist nysgerrighed over for fremmede folk eller kulturer. At dette stadig er tilfældet, ser han bekræftet i Arab Human Development Report 2003 som påpeger, hvor få bøger der historisk og i dag bliver oversat til arabisk. Man kan kun give ham ret $i$, at det ville være godt, om det brede arabiske publikum læste flere bøger i oversættelse fra europæiske eller andre sprog. Det er naturligvis altid godt. Men som bevis på en påstået mangel på nysgerrighed over for andre kulturer er det selvfølgelig ikke tilstrækkeligt. Og det er da gennemgående heller ikke rigtigt.

Historisk set var araberne ikke blottet for nysgerrighed; de rejste vidt omkring - til Kina, Indien, Afrika, Indonesien, Mongoliet, endog Norden - og rejseberetningen var en elsket genre, som i 1800-tallet blev genopdyrket med nye rejser til Frankrig, England og Japan. Heller ikke rationalisme er frem- 
med for arabisk kultur. Når Ibn Warraq siger, at islamisk filosofi "for many Western scholars, and many Muslims" skulle være "a contradiction in terms" (s. 64), så er det egentligt ret selvudleverende - $\mathrm{i}$ alt fald for disse vestlige forskere (hvem de så end er) og ham selv. For det betyder jo, at deres prækonciperede idéer om, hvad islam (og filosofi) bør være, er så stærke, at de er fristet til at benægte kendsgerninger, snarere end at forlade deres opfattelse. For der var en stærk filosofisk bevægelse i den arabisk-persiske verden fra 800-tallet og fremad, og selv om den mødte modstand fra puritansk hold, overlevede både dens værker og dens tradition (særligt i Persien) igennem århundrederne. Ligeså vigtigt er det, at der også var rationalistiske skoler i islamisk logik, grammatik, retslære og teologi. At kalde islamisk filosofi for en selvmodsigelse vil netop sige, at man har en så dogmatisk overbevisning om en islamisk irrationalisme, at den styrer, hvad man vil se. Det kan vi efter min mening godt kalde orientalisme, i ordets negative betydning.

Endnu mere oplagt er det, at man fra 1800-tallet og frem blev umådeligt interesseret $i$ at lære fra europæernes videnskaber, og man oversatte bøger, udsendte studerende til Europa eller inviterede europæiske lærere til at slå sig ned. Hvorfor skal det ikke nævnes? Når man så taler om, hvor få bøger der oversættes til arabisk (bemærk hvordan han løbende skifter mellem islamisk og arabisk - der er andre muslimske sprog som har en større oversættelsestradition), så er det sandt, at mange arabere (muslimer som kristne) ikke er synderligt interesserede i europæisk finkultur. Men det skal med i billedet, at der er veluddannede lag $\mathrm{i}$ befolkningen, som har den interesse og hyppigt læser europæiske værker på originalsproget - for sådanne bøger kan købes i de fleste større arabiske byer. Dertil kommer, at mange af de idéer som disse bøger rummer, alligevel cirkulerer rundt - dels gennem piratoversættelser og plagiater (for der er meget lidt kontrol med copyright i arabiske lande), dels i de andre medier, hvor mange emner tages til behandling.

Medierne vil også være et udmærket sted at gå til, hvis man skal korrigere en anden af Ibn Warraqs fejltagelser, nemlig hans påstand (s. 80), at der i den Arabiske Verden ikke findes selvkritik. Det skal man være endog meget langt fra den Arabiske Verden for at tro. Og Ibn Warraqs viden er da også kun baseret på dårligt underrettede anti-arabiske polemikere. Men læser man arabiske aviser, er der masser af - mere eller mindre kvalificeret - arabisk selvkritik. Og igen er arabisk ikke det samme som muslimsk. Kritik af hele ens egen kultur er i øvrigt ikke noget vi fordrer af andre end araberne; vi praktiserer det ikke selv, og vi har lige overværet et amerikansk valg, hvor alle kandidater igen og igen hyldede denne jordens bedste nation.

\section{Grænser for selvkritikken}

Anden del af Ibn Warraqs bog afsluttes med et kapitel om "Edward Said and his methodology", hvor denne kritiseres for sin slaphed med historiske kilder og for at give Vesten skylden for alt ondt. Over halvdelen af kapitlet (17 sider) 
er en illustration af denne ensidighed i den tredje verden, ved at gennemgå hvordan også denne verden (arabere, afrikanere, asiater) handlede og holdt slaver i et kolossalt omfang, mens det alligevel i dag kun er Europa og USA, der bebrejdes, og som har taget skylden på sig. Dette er rigtigt og en vigtig pointe, men her ender Ibn Warraq som sædvanligt i den modsatte grøft, når han frakender den øvrige verden enhver rolle i forbindelse med ophævelsen af slaveriet. Abolitionismen udgik ganske rigtigt fra Europa, som hele tiden også var drivkraften, men som påpeget $\mathrm{i}$ en nylig bog af William Gervase Clarence-Smith, var der trods alt mange muslimer involveret i denne kampagne, som næppe var lykkedes uden dem. Saids bog beskæftiger sig imidlertid ikke med slaveri, men med visse kolonialistiske ideologiers opfattelse af orientalerne. Det forekommer derimod ubegrundet, at Ibn Warraq selv vælger at forbigå kolonialismen og dens også meget graverende militære nedkæmpelser, undertrykkelse og herrefolks-ideologier, for alene at fokusere på et punkt, ophævelsen af slaveriet, hvor kolonialismen vitterligt også kom mennesker i Afrika og Asien til gode.

På samme måde fortsætter Ibn Warraq med at give eksempler på racisme i den arabisk-muslimske verden, og nutidig islamisk anti-semitisme, som han søger at føre tilbage igennem århundrederne som en evig islamisk komponent (254-60), ikke mindst i det middelalderlige muslimske Spanien. Igen: det er rigtigt, at det muslimske Spanien ikke var den harmoniske smeltedigel, som man til tider ser folk gøre det til i dag. Men der var faktisk lange perioder med fredelig sameksistens - en sameksistens, der brat sluttede med forfølgelser og fordrivelser af både jøder og muslimer efter generobringens afslutning i 1492. Hvorfor skal vi ikke høre det? Og selv om Ibn Warraq med sin sædvanlige sprogbrug prøver at hippie-gøre enhver der mener, at den anti-semitisme, man ser i dag i den Arabiske Verden, primært er importeret fra Europa (noget der ikke undskylder den det mindste), så er han her som mange steder oppe imod en ret etableret forskning (inklusive Bernard Lewis' The Jews of Islam) der har fastslået, at jøderne gennemgående var væsentligt mindre forfulgt $\mathrm{i}$ den muslimske verden end i Europa. Denne konklusion vælger Ibn Warraq at ignorere til fordel for citater fra andre polemikere af hans egen slags.

Et sidste kapitel, "The Pathological Niceness of Liberals, Antimonies, Paradoxes, and Western Values" forklarer, at de tre gyldne tråde i den vestlige tradition også kan overdrives, idet rationalisme kan føre til scientisme, universalisme kan føre til kosmopolitanisme (sic!) og selvkritik kan føre til selvhad, "as witnessed in the buffooneries of Michael Moore, the exaggeration of Robert Fisk, and the fanaticism of Noam Chomsky". Det fører til det tvivlsomme postulat, at mange amerikanske liberale ikke har turdet taget ordet islam i deres mund, når de talte om den 11. September (s. 277). I kort og stakåndet form kører Ibn Warraq nu igennem islamisk fundamentalisme, romantiseringen af østlig mystik og naturfolks religion. Et overraskende skift får ham dog til at medgive, at den "islam" han har talt om, faktisk er en historisk 
størrelse og som sådan foranderlig (s. 284), samt at der historisk har været en ret markant adskillelse mellem stat og religiøse samfund i den muslimske verden (s. 286).

Meget af, hvad Ibn Warraq skriver her, virker tilfældigt og lidet gennemarbejdet. Enhver kritisk læser vil føle, at her helliger hensigten midlet, og dermed også en ædruelig omgang med forskningen og dens kilder. Ibn Warraq ophober anklager imod den muslimske verden med grelle eksempler, men uden rigtigt at undersøge hvor meget der er om snakken, og hvorfor, og med konsekvent selektion i sine hjemmelsmænd. Når han skal forklare, at de islamiske fundamentalister ikke bliver radikale på grund af deres situation her i livet, citeres Benjamin Netanyahu for, at de hader Israel, fordi Israel er en del af Vesten, og Netanyahus tidligere rådgiver David Wurmser for, at liberale tillægger emner som jord og velstand alt for megen betydning (s. 275). Man kunne jo overveje, om disse kommentatorer havde en politisk hensigt med det, de sagde, og om man evt kunne finde folk, der mere indgående havde beskæftiget sig med islamisterne og deres rekruttering og bevæggrunde. Resultatet er en ensidighed, en indignation og en selvretfærdighed på vegne af den strålende vestlige civilisation, der lader hån om den rationalisme og selvkritik, som den har sat sig for at forsvare. I en bizar digression (s. 278) om indianernes i virkeligheden meget begrænsede antal ord for sne, uanset hvad vestlige liberale ellers måtte tro, havde det virket helt passende med bare en enkelt kommentar om udryddelsen af indianerne i en bog, der angiveligt er et forsvar for vestlig civilisation, inklusive dens selvkritik.

\section{Kritik af orientalisterne - nu fra modsat hold}

Irwin og Warraq er langt fra de første der kritiserer Said - hvilket de da også gør opmærksom på. Reaktionerne på bogen blandt fagfolk i orientalistikken var forståeligt nok noget behersket. Nogle afviste Orientalism som et politisk makværk, der rodede videnskaben sammen med alt muligt andet. Mange kunne påpege fejl og ret graverende mangler i Saids bog, der jo også udgav sig for at være en faghistorie. Men selv blandt dem, der fandt, at bogen var en dårlig faghistorie, var der dog mange, som også fandt, at der var behov for et begreb om en særlig vestlig anti-orientalsk attitude, der anså folk fra den del af verden som fundamentalt anderledes end andre mennesker, og som havde sat sig talløse spor i vestlig populærkultur.

Atter andre fandt imidlertid, at Saids kritik af faget selv var berettiget. Det var også sådan, at Orientalism faktisk kom efter halvandet årtis selvopgør i faget. Der var en yngre venstreorienteret generation, særligt i England (centreret om tidsskriftet Review of Middle East Studies), som så faget som kolonialistisk og forstokket, med sin vældige fokus på sprogudvikling og litteratur-historie, og uden forbindelse med nyere teori-dannelse i andre fag. De var altså enige i Saids kritik - og sikkert også i hans politiske holdninger - men de var dog samtidigt opmærksomme på, at også Saids bog først og fremmest var en litte- 
ratur-historie, nu med den vestlige litteratur om Orienten som sit objekt. For disse yngre forskere, som ofte var historikere, var historien skabt af interesser, klasser, magt, ressourcer, teknologi, sygdomme og sult, og kun i mindre grad af idéer, og slet ikke af litteratur. I deres øjne lignede Said derfor ironisk nok sin egen yndlingsaversion, den kendte orientalist Bernhard Lewis. I Frankrig udgav den kendte venstreorienterede orientalist Maxime Rodinson i 1980 en klar og kort fremstilling af orientalistikkens historie, Europe et la fascination de 'l-Islam, der slutter med en status over faget i dag, som bekræfter kritikken af den mere ureflekterede orientalistiks "teologocentri" (priviligering af islam som forklaring i sig selv), men samtidigt rummer nogle skarpe bemærkninger om Saids manglende forståelse af faget.

Said havde også beundrere i faget, og Orientalism blev læst vidt og bredt. Hertil bidrog også Saids aggressive stil, hans medietække og hans bredere politiske engagement på venstrefløjen. 1980erne og 90erne var ekspansionsår i studiet af Mellemøsten, som voksede stærkt og nød godt af offentlig bevågenhed. En række studier i perioden er tydeligt inspireret af Said, eller refererer til orientalisme på den negative måde, som Said om ikke opfandt, så dog knæsatte.

Efterdønningerne fra Orientalism var dog aftaget en hel del, da angrebene på New York og Washington fandt sted den 11/9 2001. Said selv, som på dette tidspunkt var dødeligt syg, fandt en sjælden lejlighed til at kritisere sig selv for at have negligeret eller minimeret den fanatisme i den muslimske verden, som orientalister så tit havde bemærket. Det var klart, at terror-angrebet, og USA's militære opgør med al-Qaeda og Taleban i Afghanistan, rejste mange af de gamle spørgsmål om vestlig dominans og muslimsk forskellighed på ny, og i en radikal forstand. Spørgsmålet om "repræsentationen af den Anden" var med ét akut, og Saids ensidige kritik af vestlige negative stereotyper var ikke længere tilfredsstillende. Hans ideologiske modstandere kunne rykke frem.

Det voldsomste angreb havde faktisk allerede fundet sted, men blev nu meget forstørret af begivenhederne. Martin Kramer, mangeårig direktør for Moshe Dayan Centret i Israel, angreb i bogen Ivory Towers Built on Sand (2001) den amerikanske mellemøstforskning og dens organisation Middle East Studies Association (MESA) for at være så angst for kritik fra Said, eller så infiltreret af Saids tilhængere, at den veg tilbage for eller ligefrem fordømte hårdkogt kritik af de politiske realiteter i den Arabiske Verden eller islamisk ekstremisme. Kramer gjorde op med tendensen til at fokusere på civilsamfund i den Arabiske Verden, når realiteten var, at disse civilsamfund levede på de magtfulde autoritære regimers nåde. Ligesom han gjorde grin med visse forskeres søgen efter "muslimske Luthere", fordi Mellemøstens politik i det store og hele har været sekulær i årtier - takket være de samme autoritære regimer - mens omvendt stærkt liberale udlægninger af islam de seneste årtier har været på tilbagetog. 
Kramer, som vel at mærke er en god kender af Mellemøsten i det 20. århundrede, mente altså ligesom Edward Said, at der var noget galt med amerikansk mellemøst-forskning i dag. Men her holdt ligheden også op. For problemet var i Kramers øjne netop, at der var sket et brud med orientalistikken - som i hans øjne havde været upolitisk - og at man i stedet havde fået en stærkt politiseret videnskab, der var blevet skamløst pro-arabisk og anti-israelsk - som følge af Edward Saids angreb. Forskningen var i det store og hele anstændig før Said, mens intet duede efter ham.

Kramers kritik var ensidig og unfair. For selv om studiet af emner som civilsamfundet i Mellemøsten vel nok fyldte lovligt meget og hos nogle forskere var omgærdet af et vist mål af wishful thinking, så manglede amerikansk mellemøst-forskning ikke kontante analyser af stater, regimer, eliter, menneskerettigheds-krænkelser, islamistisk militarisme eller patriarkalsk kultur. Den fløj i forskningen, han angreb, var ikke blid over for de arabiske regimer, men den var samtidigt stærkt kritisk over for Israel - og dermed over for USA's politik i området. Kramer angreb amerikansk mellemøst-forskning for at være upatriotisk og gav eksempler på, at den kritiserede USA's rolle. Men det er ikke forskningens opgave at være patriotisk. Og det var formentligt kun lige omkring 2001, at det argument kunne have virkning i den amerikanske debat. Kramers erklærede hensigt var da også politisk i en grad, som Saids aldrig havde været: han lobbyede for en tættere politisk kontrol og definition af, hvad der skulle studeres i amerikanske mellemøst-studier.

Fra at have været den aggressive angriber, var Said nu den, der blev angrebet. Og med ham hele feltet af Mellemøst- og islam-studier, der blev set som saidiansk inficeret. Det samme felt, som Said havde angrebet for at være imperialismens hjælper, blev nu af Kramer hængt ud som anti-vestligt og moderigtigt tredjeverdens-forgabt. Dette faldt i begyndelsen af 2000-tallet sammen med en bredere anti-akademisk tendens, der anskuede samfunds- og humaniora forskere for at være langt fra den virkelige verden og mere optaget af at imponere kolleger med vanskelige fremmedord, end med at undersøge deres genstandsfelt. Internettets mange barske hjemmesider med "menighedsblade", hvor folk der var enige kunne hælde fornærmelser og ukvemsord ud over dem, de var uenige med, har spillet en vis rolle i mobiliseringen af dette anti-akademiske klima.

\section{Konklusion: \\ orientalister, anti-orientalister og anti-saidister}

Irwin og Ibn Warraq har travlt med at demonstrere, at de klassiske orientalister ikke var politiske og kun havde svage forbindelser til imperialismen. Det synes jeg som sagt er en position, de har vanskeligt ved at forsvare, men i øvrigt slet ikke behøvede at indtage. Tager man imperialismens gyldne epoke, fra 1870 til 1914, så spillede de store europæiske stater en voksende rolle i finansieringen af lærestole, tidsskrifter og kongresser, og det var naturligvis 
fordi orientalisternes viden var vigtig - omtrent som det nu igen er tilfældet efter 2001. Det kunne føre til dårlig, politisk dikteret forskning. Men også til god forskning, f.eks. i teams og med store ressourcer, og til en helt ny generation af godt researchede akademiske tidsskrifter, såsom det franske Revue du monde musulman et de la Méditerranée og tilsvarende tyske og italienske tidsskrifter i første halvdel af det 20 århundrede. Der var med andre ord en vigtig nutids- og samfunds-relateret orientalistisk forskning, som hverken Irwin, Ibn Warraq eller Said selv kender til. Said kunne have benyttet den til at påpege forbindelserne til imperialismen, men omvendt havde det undermineret hans fremstilling af forskningens billede af den muslimske verden som statisk; de nye tidsskrifter var meget explicitte i deres overbevisning om, at der fandt dramatiske udviklinger sted i de muslimske lande. Så selv om Said ikke er særligt god til det, er det altså ikke svært at påvise tætte forbindelser mellem kolonialismen og orientalistikken, eller dele af den, for der var også anti-imperialistiske forskere.

Både Irwin og Ibn Warraq finder, at det er et argument imod Said, at den tyske forskning (som Said, formodentlig af sproglige grunde, forbigår) var stærkt dominerende i det 19. århundredes orientalistik, men at Tyskland ikke havde kolonier i Mellemøsten. Det er rigtigt, at Tyskland var dominerende. Det er også rigtigt, at Tyskland ikke havde kolonier i Mellemøsten. Men for det første havde Tyskland kolonier med muslimske befolkninger andre steder (i Østafrika), for det andet håbede man længe også at få nogle i Mellemøsten (særligt Marokko), for det tredje var man imperialistisk aktiv i Mellemøsten ved at indgå $i$ en tæt alliance med det Osmanniske Rige, og for det fjerde havde Kaiser Wilhelms Tyskland en formuleret "Islam-Politik" rettet imod at gøre verdens muslimer pro-tyske. Adskillige orientalister var involveret $\mathrm{i}$ denne "Islam-Politik" i årtiet før første verdenskrig (og under krigen). Saids udeladelse af den tyske orientalistik gør "Orientalism" ubrugelig som faghistorie. Men argumentet om, at det demonstrerer orientalistikkens manglende forbindelse til imperialismen, holder på den anden side heller ikke.

Skønt de også siger det modsatte, kommer Irwin og Ibn Warraq altså til at bekræfte den Saidske holdning, at forbindelse til imperialismen nødvendigvis betød, at forskningen var kompromitteret og dårlig. Det er derfor, de bruger så mange kræfter på at rense orientalisterne for beskyldningen. Men der var som sagt mange forbindelser - og hvordan skulle det også have været anderledes? I det hele taget virker forsøget på at gøre forskerne verdensfjerne indtil udgivelsen af Orientalism i 1978, og derefter pludseligt uudholdeligt politiske, som temmelig naivt.

Politiske forbindelser og holdninger er én ting, og dårlig forskning en anden. Hvis man ligefrem undertrykker dele af sin viden, eller ikke opsøger den, fordi det vil kompromittere éns (eller andres) politiske holdninger, så er det naturligvis et problem. Men at man kommer til feltet med bestemte erfaringer og anskuelser, og at de kan få betydning for éns valg af emner, er ikke 
i sig selv en utilbørlig politisering. Said fandt, at orientalisterne havde været mere politiske, end de ville være ved. Saids kritikere påviser, hvor politiske Said og hans elever har været, og de hævder, at han har skabt en dræbende politisk korrekthed. At disse kritikere selv har deres egen politiske korrekthed, synes ligeledes klart. Det interessante er imidlertid ikke, om de var politiske, men om de var korrekte i deres analyser og belæg for deres påstande. For, som Ernest Gellner sagde, så falder sandheden, ligesom regnen, både på den retfærdige og den uretfærdige.

Den pointe er værd at fastholde i dag, hvor islamisme, terrorisme og integrationsproblemer blandes sammen til en uspiselig vælling under navnet islam. Og hvor folk, der aldrig har sat deres ben i en muslimsk by, læser Koranen og mener sig kvalificerede til at forklare og fælde dom om denne islam. I tilfældet Ibn Warraq og hans disciple føres denne agitation med akademiske citater og "kritisk" sprogbrug. Det er bare en anvendelse af ordet kritik, der ikke lever op til det bedste i den rationalisme, han hylder. Det skyldes, at den ikke er metodisk og selvkritisk, men alene søger at underbygge en politisk position.

Altfor ofte anvendes ordet kritisk positionelt, dvs at det henviser til at man indtager en bestemt politisk position, som heroisk strider sig op imod "den herskende mening" - på 1970ernes venstrefløj kaldet "borgerligheden", i dag snarere "den politiske korrekthed". Det er altså alene ved sit standpunkt, man er kritisk, og ikke ved sin prøvende holdning. For den er der typisk meget lidt af. Man kan som Ibn Warraq, ellers hans epigoner på internettet, kopiere store blokke tekst fra allemulige kilder, der mener det samme som én selv, og så kalde sig kritisk. Der er naturligvis folk på den politisk modsatte fløj, der gør præcist det samme og også kalder sig kritiske.

Denne udbredte anvendelse af ordet kritisk står i kontrast til den mere klassiske opfattelse af kritisk stillingtagen, dvs. at undersøge hvad vi ved og hvordan vi kan vide det og teste det, og konkludere "sine ira et studio" helt uden skelen til, om resultatet er populært eller ej. Når det kommer til emnet islam, så er det min opfattelse, at den klassiske form for kritisk stillingtagen har fået vanskelige kår i den offentlige debat, hvor den positionelle case-building dominerer. Men den klassiske prøvende kritiske stillingtagen overlever udmærket i fagtidsskrifter, seminarer og andre akademiske institutioner.

Man kan her til sidst spørge sig selv, hvorfor Edward Saids Orientalism fik så stor en gennemslagskraft, når den nu på så mange måder misforstod den faghistorie, den hævdede at beskrive. En af grundene er naturligvis en ukritisk holdning hos mange læsere, som ikke kendte noget videre til orientalistikkens historie, men var interesseret i bogens implikationer: dens kritik af den vestlige verdens intellektuelle dominans, dens politisering af videnskab, dens perspektivisme. Bogen rummede jo også mange muligheder; der var så at sige nok at tage fat på, når megen forskning ikke længere kunne tages for gode varer, og når der åbnede sig nye spændende muligheder for at samtænke vestlig 
politisk dominans, idehistorie og udviklinger i andre steder i verden. Folk der havde specialiseret sig i fjerne kulturer eller tider kunne nu omdirigere deres arbejde og give det politisk engagement. Et stort felt åbnede sig i studiet af det fremmede i et dialektisk forhold til egne selv-forståelser. Her har Said faktisk inspireret megen god forskning, hans egne forsimplinger til trods.

Men efter min mening er der også en anden grund. Nemlig, at mange med lethed kunne se, at orientalismen faktisk findes. Her tænker jeg ikke på den akademiske disciplin, orientalistikken, men på det bredere fænomen, som Said anklagede den for at have skabt. Nemlig en ideologi om Orientens absolutte anderledeshed, hvor den står som modbilledet til alt vestligt, der gennemgående defineres i positive termer. Som Said skriver, fremstilles Orienten som anderledes, underlegen, irrationel og først og fremmest statisk. Det synes jeg ikke man skal lede længe i sine omgivelser for at se eksempler på. Og at det er en forsimplende ideologi, kan der ikke herske tvivl om, uanset hvor mange uhyrligheder de enkelte mennesker i det man engang kaldte Orienten kan finde på at sige eller gøre. At forklare sådanne udsagn eller handlinger alene med ordet kultur, vil aldrig være tilstrækkeligt forklarende, og ofte bare cirkulært. Desuden er det afgørende at huske på, at der også vil være mange mennesker i Mellemøsten, for hvem disse uhyrlige udsagn eller handlinger er lige så fremmede, som de er for folk her. Orienten er ikke en forklaring på noget som helst, lige så lidt som Vesten er det. Mener man med Orienten i virkeligheden Mellemøsten, gør man desuden klogt i at medtænke talløse former for kontakt og inspiration til og fra Europa, og siden 1800-tallet også de voldsomme (og fælles) moderniseringer og transformationer, som gør, at de og vi på mange områder ligner hinanden langt mere, end vi ligner vore egne tipoldeforældre.

Robert Irwin beskriver i Af begær efter viden den faktiske udvikling af et europæisk akademisk fag, orientalistikken. Ibn Warraq derimod beskriver ikke en specifik fagtradition, men et stort og uspecificeret Vesten, som han karakteriserer ved forskellige idealer, hvis modbillede han så identificerer $\mathrm{i}$ en åbenbart helt statisk "islam" (hvormed han for det meste mener den Arabiske Verden). Selv om en hel del af Ibn Warraqs kritik af Edward Said i mine øjne er helt på sin plads, så ender han alligevel med at opstille den form for nuanceløs og ensidig opdeling mellem "Vesten" og "islam" som to civilisationer, der hver for sig er homogene og karakteriseret af bestemte grundidéer eller attituder. Lige den påstand, eller ideologi, har jeg intet andet ord for end orientalisme - skønt det efterhånden er veldokumenteret, at hverken malerskolen eller det akademiske fag har været så inficeret af den, som Said påstod for tredive år siden.

Jakob Skovgaard-Petersen

E-mail: jsp@hum.ku.dk 